\title{
Pengaruh Kemandirian dan Minat Belajar Terhadap Prestasi Belajar Ilmu Pengetahuan Sosial
}

\author{
Arief Muda Kusuma \\ Universitas Indraprasta PGRI
}

\begin{tabular}{l}
\hline ARTICLE INFO \\
\hline Article History: \\
Received May $28^{\text {th }}, 2021$ \\
Revised Aug $6^{\text {th }}, 2021$ \\
Accepted Aug $16^{\text {th }}, 2021$
\end{tabular}

\section{Keywords:}

Independence;

Interest in Learning;

Social Sciences Learning

Achievement.

\begin{abstract}
The research aims to analyze and test the truth of hypotheses regarding the influence of learning independence and interest in the learning achievement of Private Junior High School students in South Jakarta. The research hypotheses tested include: There is an influence of independence and interest in learning together on the learning achievement of Private Junior High School Students in South Jakarta. There is an influence of independence on the learning achievement of Private Junior High School Students in South Jakarta. There is an influence of learning interest on the learning achievement of Social Sciences Private Junior High School Students in South Jakarta. The research was conducted by survey method. Analyzed using multiple regression analysis. The results of hypothesis testing came to the following conclusion: 1) There is a significant influence of independence and interest in learning together on the learning achievement of Private Junior High School Students in South Jakarta. This can be proven by the value of Sig. $0.000<0.05$ and $F h=97,679$. 2) There is an insignificant influence of independence on the learning achievement of Private Junior High School Students in South Jakarta. This can be proven by the value of Sig. $=0.727>0.05$ and $t_{h}=0.351$. 3) There is a significant influence of learning interest in learning achievements of Private Junior High School Students in South Jakarta. This can be proven by the value of Sig. $=0.000<0.05$ and $t_{h}=$ 8,680 .
\end{abstract}

Penelitian bertujuan untuk menganalisis dan menguji kebenaran hipotesis mengenai pengaruh kemandirian belajar dan minat terhadap prestasi belajar IImu Pengetahuan Sosial Siswa SMP Swasta di Jakarta Selatan. Hipotesis penelitian yang diuji meliputi terdapat pengaruh kemandirian dan minat belajar secara bersama-sama terhadap prestasi belajar IImu Pengetahuan Sosial Siswa SMP Swasta di Jakarta Selatan, terdapat pengaruh kemandirian terhadap prestasi belajar IImu Pengetahuan Sosial Siswa SMP Swasta di Jakarta Selatan, dan terdapat pengaruh minat belajar terhadap prestasi belajar IImu Pengetahuan Sosial Siswa SMP Swasta di Jakarta Selatan. Penelitian dilakukan dengan metode survei dan dianalisis dengan menggunakan analisis regresi ganda. Hasil pengujian hipotesis diperoleh simpulan sebagai berikut: 1) Terdapat pengaruh yang signifikan antara kemandirian dan minat belajar secara bersama-sama terhadap prestasi belajar IImu Pengetahuan Sosial Siswa SMP Swasta di Jakarta Selatan. Hal ini dapat dibuktikan dengan nilai Sig. $=0,000<0,05$ dan $F h=97,679$. 2) Terdapat pengaruh yang tidak signifikan kemandirian terhadap prestasi belajar Ilmu Pengetahuan Sosial Siswa SMP Swasta di Jakarta Selatan. Hal ini dapat dibuktikan dengan nilai Sig. $=0,727>0,05$ dan th $=0,351$. 3) Terdapat pengaruh yang signifikan minat belajar terhadap prestasi belajar IImu Pengetahuan Sosial Siswa SMP Swasta di Jakarta Selatan. Hal ini dapat dibuktikan dengan nilai Sig.= $0,000<0,05$ dan th $=8,680$.

Corresponding Author:

Arief Muda Kusuma,

Email: Mudaarief9@gmail.com

How to Cite: Kusuma, A.M. (2021).Pengaruh kemandirian dan minat belajar terhadap prestasi belajar ilmu pengetahuan sosial. Sosio e-Kons, 13 (2), 122-128.http://dx.doi.org/ 10.30998/sosioekons.v13i2.9802 


\section{PENDAHULUAN}

Pendidikan merupakan suatu kegiatan yang universal karena di mana pun, kapan pun dan dengan bentuk apa pun di dunia terdapat kegitan pendidikan. Pendidikan pada hakikatnya merupakan usaha manusia untuk memanusiakan manusia. Hal ini berarti dengan pendidikanlah manusia akan menjadi manusia seutuhnya yang memiliki moral dan nilai dalam menjalankan kehidupan.

Para pendiri bangsa ini memiliki keyakinan bahwa dengan pendidikan maka bangsa Indonesia akan memiliki martabat yang tinggi dan yang dapat sejajar dengan bangsa-bangsa lain di dunia. Keyakinan ini dapat dilihat dalam Undang-Undang Dasar 1945 dan UUD 1945 perubahan tahun 2006 mengenai pendidikan, Bab XIII pasal 31 ayat (1) yang menyatakan "Setiap warga negara berhak mendapatkan pendidikan". Kata berhak disini menunjukkan bahwa begitu pentingnya pendidikan sehingga siapapun anak bangsa harus memiliki akses dan kesempatan yang sama dalam mengikuti proses pendidikan.

Pendidikan diyakini dapat digunakan sebagai alat perjuangan dalam membangun bangsa. Pembangunan nasional merupakan manifestasi tanggung jawab kebangsaan dalam mewujudkan citacita kemerdekaan. Dengan diadakanya pembangunan nasional yang berkelanjutan akan terwujud kemandirian, daya saing, dan dapat melihat serta memanfaatkan peluang dalam pergaulan ekonomi sosial dan politik dunia.

Dalam rangka mewujudkan cita-cita tersebut diperlukan sumber daya manusia berkualitas dengan usaha mencerdaskan dan menumbuhkembangkan kreativitas, disiplin, beretos kerja, beriman dan ber-Taqwa kepada Tuhan Yang Maha Esa, dan ini hanya dapat terwujud melalui kegiatan pendidikan. Ditegaskan dalam Undang-Undang Nomor 20 Tahun 2003 tentang Sistem Pendidikan Nasional Bab II pasal 3, disebutkan dasar, fungsi, dan tujuan pendidikan adalah mengembangkan kemampuan dan membentuk watak serta beradaban bangsa yang bermartabat mencerdaskan kehidupan bangsa dengan proses mendorong berkembangnya peserta didik menjadi manusia yang beriman dan bertaqwa terhadap Tuhan Yang Maha Esa, berakhlak mulia, sehat, berilmu, cakap, kreatif, mandiri dan menjadi warga negara yang demokratis serta bertanggung jawab.

Selanjutnya, pendidikan juga berfungsi mengembangkan kemampuan dalam membentuk watak serta peradaban bangsa yang bermartabat dalam rangka mencerdaskan kehidupan bangsa, bertujuan untuk mengembangkan potensi peserta didik agar menjadi manusia yang beriman dan bertakwa kepada Tuhan Yang Maha Esa, berakhlah mulia, sehat, berilmu, cakap, kreatif, mandiri, dan menjadi warga negara yang demokratis serta bertanggung jawab (Widyaningrum, 2016). Pada kenyataannya prestasi belajar peserta didik saat ini belum seperti yang diharapkan. Dibuktikan dari penelitian sebelumnya mengenai "Pengaruh Motivasi Belajar dan Persepsi Siswa tentang Metode Mengajar Guru terhadap Prestasi Belajar Memproses Dokumen Dana Kas Kecil Peserta didik Kelas XI Akuntansi SMK Negeri 4 Klaten Tahun Ajaran 2016/2017" oleh (Cahyaningrum, 2017).

(Kompas, 2021), menyebutkan pengertian kemandirian adalah kemampuan remaja dalam berpikir, merasakan dan membuat keputusan secara pribadi berdasarkan diri sendiri dibandingkan mengikuti apa yang orang lain percayai. Kemandirian belajar siswa diperlukan agar mereka mempunyai tanggung jawab dalam mengatur dan mendisiplinkan dirinya, serta mengembangkan kemampuan belajar atas kemauan sendiri. Sikap-sikap tersebut perlu dimiliki oleh siswa sebagai peserta didik karena hal tersebut merupakan ciri dari kedewasaan orang terpelajar. Siswa telah mampu belajar secara mandiri apabila telah mampu melakukan tugas belajar tanpa ketergantungan dengan orang lain (Majid, 2021).

Teori-teori yang dikemukakan di atas dapat diartikan bahwa ciri-ciri peserta didik yang memiliki kemandirian adalah sebagai berikut :

1. Inisiatif pada kegiatan belajar

Komponen ini meliputi kemampuan berpikir dan bertindak yang original, kreatif, penuh inisiatif dan tidak mengharapkan penghargaan dari orang lain. Kreativitas peserta didik dimungkinkan 
tumbuh dan berkembang apabila lingkungan keluarga, masyarakat, dan sekolah turut menunjang mereka dalam mengekspresikan inisiatifnya.

2. Kemantapan atau percaya diri dalam setiap kegiatan belajar.

Kepercayaan diri adalah sikap positif seorang individu yang memampukan dirinya untuk mengembangkan penilaian positif baik terhadap diri sendiri maupun terhadap lingkungannya. Hal ini bukan berarti bahwa individu tersebut mampu dan berkompeten melakukan segala sesuatu seorang diri alias "sakti". Rasa percaya diri yang tinggi sebenarnya hanya merujuk pada beberapa aspek dari kehidupan individu tersebut, dimana ia merasa memiliki kompetensi, yakin, mampu, dan percaya bahwa dia bisa karena didukung oleh pengalaman, potensi aktual, prestasi serta harapan yang realistik terhadap diri sendiri.

3. Tanggung jawab dalam setiap aktivitas belajarnya.

Manusia memiliki kemampuan untuk mengambil inisiatif dalam menunjukkan tanggung jawab terhadap setiap gagasan, kata dan tindakan, apapun konsekuen yang ditimbulkannya. Kemampuan bertanggung jawab yang sangat penting adalah rasa tanggung jawab terhadap diri sendiri. Seseorang bertanggung jawab dalam mengontrol, menguasai dan mengendalikannya sendiri. Kemandirian seseorang ditandai dengan adanya kecenderungan untuk mengambil sikap penuh tanggung jawab.

Terdapat dua faktor yang mempengaruhi kemandirian peserta didik, yaitu faktor internal dan faktor eksternal.

1. Faktor Internal

Adalah faktor yang ada atau berasal dari dalam diri individu, antara lain : inteligensi, bakat, dan kemampuan. Jika seseorang memiliki inteligensi yang tinggi terutama inteligensi belajar, maka dapat beraktivitas dalam belajar secara efektis

2. Faktor Eksternal

a. Faktor Keluarga.

Keluarga sebagai lingkungan pertama dan utama dalam kehidupan anak tempat ia belajar sebagai individu sosial dalam berinteraksi dengan kehidupan keluarganya. Pengalaman interaksi dikemudian hari dalam keluarga turut menentukan perilaku anak di kemudian hari. Struktur dalam keluarga (utuh tidaknya keluarga) dan keadaan sosial ekonomi keluarga memiliki pengaruh terhadap tumbuh dan perkembangan anak.

b. Faktor Sekolah.

Pengaruh pendidikan di sekolah memiliki peran yang cukup besar terhadap kemandirian anak (peserta didik). Sekolah tidak hanya berperan memberi pengetahuan, juga sebagai penyelenggara pendidikan, pengajaran, latihan dan bimbingan. Oleh sebab itu, peran guru selain mengembangkan kemapuan akademik anak (peserta didik) juga berperan membimbing mereka agar mampu mandiri dalam belajar.

c. Faktor Masyarakat.

Masyarakat dan budaya memberi pengaruh terhadap warganya, yang menyangkut cara berpikir, bersikap, dan berperilaku. Seorang anak mempunyai kemandirian yang baik apabila mendapat lingkungan masyarakat yang baik juga dan sebaliknya. Keterkaitan dengan pendapat di atas, maka dapat disimpulkan faktor eksternal dalam kemandirian peserta didik dapat dilakukan melalui : (1) pembinaan dan (2) pembiasaan dan pemberian kesempatan, seperti teladan, anjuran, perintah, latihan, pujian, dan hukuman.

Menurut Ratnasari (2017) bahwa minat belajar cenderung menghasilkan prestasi yang tinggi sebaliknya minat belajar yang kurang akan menghasilkan prestasi belajar yang rendah. Pada saat siswa lainnya ribut didalam kelas dan mengobrol dengan suara yang keras pada saat guru menjelaskan pelajaran, maka dapat menyebabkan siswa yang lainnya tidak dapat memperhatikan pelajaran dengan baik dan tentunya jika tidak bisa memperhatikan dengan baik siswa tersebut akan kehilangan minat dalam belajar 
Kemandirian belajar adalah suatu keterampilan belajar yang dalam proses belajar individu didorong, dikendalikan, dan dinilai oleh diri individu itu sendiri (Silvia Yanti, 2017). Menurut Hamalik (2016:27) belajar adalah modifikasi atau memperteguh kelakuan melalui pengalaman. Belajar merupakan suatu proses, suatu kegiatan, dan bukan suatu hasil atau tujuan. Belajar bukan hanya mengingat, akan tetapi lebih luas dari itu, yakni mengalami (Prasetyono, H., Ramdayana, I. P., \& Estiningsih, 2020). Hasil belajar bukan suatu penguasaan hasil latihan melainkan pengubahan kelakuan.

Pendidikan pada hakikatnya adalah suatu usaha sadar dan sistematis untuk mengubah pribadi manusia meliputi perubahan pengetahuan, sikap, dan perilaku. Pendidikan bertujuan untuk meneruskan, mengembangkan pengetahuan, dan melatih kecakapan serta keterampilan dan menyempurnakan pengetahuan manusia dalam segala kehidupan.

Pendidikan merupakan modal utama bagi seorang manusia di masa depan, karena dengan berpendidikan yang dilalui dengan proses yang baik, maka masa depan si peserta dikatakan lebih baik, sehingga berpengaruh terhadap prestasi belajar peserta didik dan pada akhirnya berujung pangkal pada keberhasilan dalam kelas.

Rusmiati (2017), menyatakan bahwa siswa yang memiliki minat belajar tinggi akan melakukan kegiatan lebih banyak dan lebih cepat, dibandingkan dengan siswa yang kurang termotivasi dalam belajar. Menurut Djamarah (Fauziah, 2017) menyatakan bahwa minat senantiasa berpindah-pindah namun demikian ia menghendaki keaktifan. Klassen (Meilani, 2021) menyatakan bahwa minat belajar merupakan keinginan dan keterlibatan yang disengaja dalam aktivitas kognitif yang memainkan bagian penting dalam proses pembelajaran, menentukan bagian apa yang kita pilih untuk belajar, dan seberapa baik kita mempelajari informasi yang diberikan. Siswa juga menjadi faktor pendukung dalam minat belajar, karena siswa memiliki motivasi dalam belajar, menyukai pelajaran, siap dalam mengikuti pelajaran dan dapat memusatkan perhatian dengan baik pada saat belajar, maka siswa akan sangat mudah memiliki minat dalam proses belajar mengajar (Prasetyono, H., \& Ramdayana, 2020).

Faktor-faktor yang utama agar tujuan pendidikan dapat tercapai dengan baik antara lain adalah adanya perubahan dan perbaikan kurikulum pendidikan yang harus selalu disesuaikan dengan perkembangan masyarakat, ilmu pengetahuan dan teknologi. Salah satu contoh adalah perbaikan dan penyempurnaan kurikulum 1994 yang terlihat pada kurikulum 2006 atau KTSP (Kurikulum Tingkat Satuan Pendidikan). Usaha penyempurnaan ini menunjukan adanya keinginan pemerintah untuk terus meningkatkan mutu pendidikan nasional yang sesuai dengan perkembangan zaman. Perubahan ini menuntut guru untuk meningkatkan profesionalisme dan kompetensinya, karena pendidikan merupakan proses belajar mengajar dimana adanya interaksi antara guru yang mengajar dengan peserta didik yang belajar, dengan kata lain prestasi belajar adalah usaha bersama antara guru dan peserta didik. Untuk memperoleh prestasi belajar yang baik, tidak cukup dari penyempurnaan kurikulum dan menyediakan guru yang berkompetensi dalam mengkomunikasikan dan mentransfer ilmu kepada peserta didik saja tapi juga diperlukan peserta didik yang mau dan siap menerima ilmu yang diajarkan guru padanya. Prestasi belajar peserta didik tidak hanya tergantung pada kualitas dan kuantitas belajar peserta didik, akan tetapi peserta didik ikut juga berperan dan bertanggung jawab atas prestasi belajar yang dicapai.

Belajar sebagai tindakan dan perilaku anak yang kompleks artinya belajar hanya dialami oleh anak itu sendiri. Proses belajar terjadi berkat anak memperoleh sesuatu yang ada di lingkungan sekitar. Lingkungan yang dipelajari oleh anak, yaitu berupa keadaan alam, benda-benda, hewan, tumbuhtumbuhan, manusia dan hal-hal yang tampak sebagai perilaku belajar. Dalam belajar faktor perubahan tingkah laku harus ada, tidak akan dikatakan belajar bila tidak ada perubahan tingkah laku.

(Nurhasanah, 2016) menyatakan bahwa minat mempengaruhi tiga aspek penting dalam pengetahuan seseorang yaitu perhatian, tujuan dan tingkat pembelajaran. Dengan adanya perhatian yang baik saat pelajaran dimulai, maka siswa cenderung memiliki perasaan tertarik terhadap materi pelajaran yang disampaikan oleh guru, hal tersebut yang mendorong siswa untuk selalu giat belajar serta mengerjakan tugas yang diberikan oleh guru salah satu yang dapat dilakukan oleh siswa adalah 
dengan mentaati peraturan-peraturan yang ada didalam kelas pada saat proses pembelajaran berlangsung khususnya pelajaran matematika materi keliling dan luas segitiga.

\section{METODE}

Berdasarkan landasan teori yang ada, maka masalah dalam penelitian ini atau variabel-variabel dalam penelitian ini dapat digambarkan sebagai berikut :

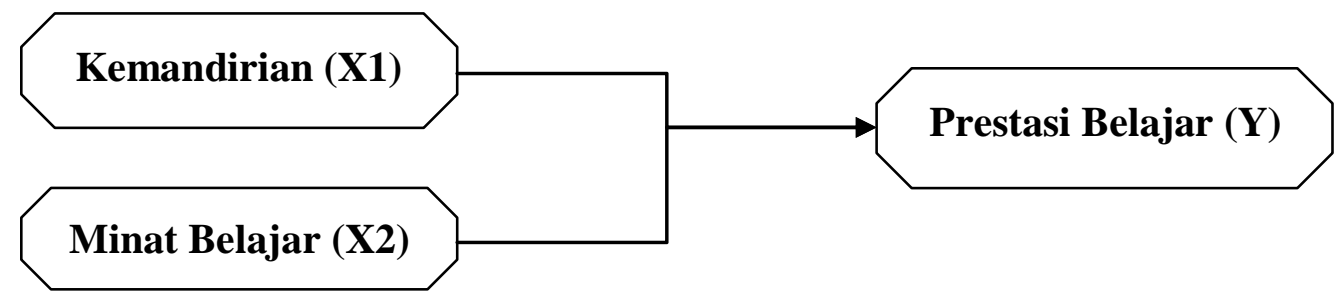

Keterangan $\quad$ Variabel independen, yaitu X1 dan X2
Variabel dependen, adalah $Y$

Penelitian ini merupakan bagian dari jenis penelitian deskriptif kuantitatif yang merupakan suatu metode dalam penelitian status kelompok manusia objek, suatu kondisi, suatu sistem penelitian ataupun suatu peristiwa pada masa sekarang.

Penelitian ini dilakukan di Sekolah Menengah Pertama Swasta di Jakarta Selatan tahun ajaran 2018/2019. Pemilihan tempat penelitian berkaitan dengan tujuan penelitian, yaitu untuk mengetahui kemandirian, minat belajar dan prestasi belajar pada peserta didik tingkat Sekolah Menengah Pertama. Dengan obyek penelitiannya adalah para siswa Kelas VII SMP Swasta di Jakarta Selatan sampel sebanyak 100 siswa di SMP Yapenka,SMP Jayakarta dan SMP Asaadah. Yang menjadi sampel adalah siswa Kelas VII pada mata pelajaran IPS.. Populasi dalam penelitian ini adalah seluruh Sekolah Menengah Pertama Swasta di Jakarta Selatan. Pengumpulan data menunjukan cara-cara yang dapat ditempuh untuk memperoleh data-data yang dibutuhkan, penulis menggunakan pengumpulan data sebagai berikut :

1. Tes

Tes dilakukan untuk mengukur nilai prestasi belajar siswa pada mata pelajaran IPS, tes yang dilakukan dengan cara diberikan soal dan kemudian soal-soal tersebut dikonversi kedalam skor nilai prestasi belajar siswa.

2. Kuesioner (Angket).

Metode kuesioner digunakan untuk memperoleh informasi atau keterangan responden mengenai kemandirian (X1) dan Minat Belajar (X2).

Adapun alat yang digunakan dalam penelitian ini berupa kuesioner dimana responden tidak diberi kesempatan untuk memberi jawaban dengan kata-kata sendiri. Responden tinggal memilih jawaban yang sudah disediakan. Dalam menyusun angket ini, digunakan skala likert, yaitu skala yang digunakan untuk mengukur sikap, pendapat, dan persepsi seseorang tentang fenomena sosial. Jawaban setiap item instrumen mempunyai gradasi dari sangat positif sampai sangat negatif yang dapat berupa katakata seperti terdapat dalam tabel gradasi jawaban angket. Semua perhitungan data penelitian menggunakan bantuan software SPSS versi 24.0. 


\section{HASIL DAN PEMBAHASAN}

Tabel 1.

Model Summary

\begin{tabular}{ccccc}
\hline Model & $\mathrm{R}$ & $\mathrm{R}$ Square & $\begin{array}{c}\text { Adjusted R } \\
\text { Square }\end{array}$ & $\begin{array}{c}\text { Std. Error of the } \\
\text { Estimate }\end{array}$ \\
\hline 1 & $.817 \mathrm{a}$ & .668 & .661 & 8.934 \\
\hline
\end{tabular}

a. Predictors: (Constant), minat.belajar, kemandirian

Dari tabel diketahui nilai korelasi simultan antara kemandirian (x1) dan Minat belajar (X2) dengan Prestasi Belajar $(Y)$ sebesar 0,817 hal ini menunjukan terdapat hubungan yang sangat kuat antara variabel tersebut secara bersama-sama. Sedangkan variable Kemandirian (X1) dan Minat Belajar (X2) secara bersama-sama memberikan kontribusi sebesar $66,8 \%$ terhadap variabel Prestasi belajar siswa $(\mathrm{Y})$.

Tabel 2.

ANOVAa

\begin{tabular}{ccccccc}
\hline & Model & Sum of Squares & df & Mean Square & F & Sig. \\
\hline 1 & Regression & 15593.524 & 2 & 7796.762 & 97.679 & $.000 \mathrm{~b}$ \\
& Residual & 7742.586 & 97 & 79.820 & & \\
& & & & & & \\
\hline & Total & 23336.110 & 99 & & & \\
\hline
\end{tabular}

Dependent Variable: Prestasi.Belajar

Predictors: (Constant), minat.belajar, kemandirian

Coefficients $^{\mathrm{a}}$

\begin{tabular}{|c|c|c|c|c|c|c|}
\hline & \multirow[t]{2}{*}{ Model } & \multicolumn{2}{|c|}{$\begin{array}{l}\text { Unstandardized } \\
\text { Coefficients }\end{array}$} & \multirow[t]{2}{*}{$\begin{array}{l}\text { Standardized } \\
\text { Coefficients }\end{array}$} & \multirow[t]{2}{*}{$\mathrm{t}$} & \multirow[t]{2}{*}{ Sig. } \\
\hline & & B & $\begin{array}{l}\text { Std. } \\
\text { Error }\end{array}$ & & & \\
\hline \multirow[t]{4}{*}{1} & (Constant) & 16.984 & 5.262 & & 3.228 & .002 \\
\hline & Kemandirian & .036 & .101 & .032 & .351 & .727 \\
\hline & $\begin{array}{l}\text { Minat } \\
\text { belajar }\end{array}$ & .989 & .114 & .793 & 8.680 & .000 \\
\hline & Total & 23336.110 & 99 & & & \\
\hline
\end{tabular}

a. Dependent Variable: Prestasi.Belajar

Pada Penelitian ini ada masalah pokok dalam rangka meningkatkan prestasi belajar siswa guru melalui penelitian terhadap beberapa faktor yang dalam penelitian ini disebut variabel. Adapun Faktor atau variabel yang mempengaruhi prestasi belajar siswa dalam penelitian ini adalah kemandirian dan minat belajar, dalam hal ini sebagai variabel yang mempengaruhi (variabel bebas), sedangkan variabel yang dipengaruhi (variabel terikat) adalah prestasi belajar siswa, maka selanjutnya perlu dibahas eksistensi masing masing variabel sebagai berikut:

1. Pengaruh kemandirian dan minat belajar secara bersama-sama terhadap prestasi belajar

Terdapat pengaruh yang signifikan kemandirian dan minat belajar secara bersama-sama terhadap prestasi belajar IPS siswa SMP swasta di Jakarta Selatan. Hal ini dibuktikan dengan peroleh nilai sig $=0,000<0,05$ dan $F_{\text {hitung }}=97,679$.

2. Pengaruh kemandirian terhadap prestasi belajar siswa

Dari hasil perhitungan dinyatakan bahwa tidak terdapat pengaruh kemandirian $\left(X_{1}\right)$ terhadap prestasi belajar siswa $(Y)$ hal ini dibuktikan dengan perolehan nilai Sig. 0,727 $<0,05$ dan $t_{h}=0,351$.

3. Pengaruh minat belajar terhadap prestasi belajar siswa

Dari hasil perhitungan dinyatakan bahwa terdapat pengaruh minat belajar $\left(X_{2}\right)$ terhadap prestasi belajar siswa $(Y)$. Hal ini dibuktikan dengan perolehan nilai Sig. 0,000 $<0,05$ dan $t_{h}=8,680$. 


\section{SIMPULAN DAN SARAN}

Terdapat pengaruh yang signifikan antara kemandirian dan minat belajar terhadap prestasi belajar IPS siswa SMP Swasta di Jakarta Selatan. Hal ini dibuktikan dengan nilai sig $=0,000<0,05$ dan $F_{\text {hitung }}=97,679$. Terdapat pengaruh yang tidak signifikan kemandirian terhadap prestasi belajar IPS siswa SMP Swasta di Jakarta Selatan. Hal ini dibuktikan dengan nilai $S i g=0,727>0,05$ dan $t$ hitung $=0,351$. Terdapat pengaruh yang signifikan minat belajar terhadap prestasi belajar IPS siswa SMP Swasta di Jakarta Selatan. Hal ini dibuktikan dengan nilai sig $=0,000<0,05$ dan $t$ hitung $=8,680$.

Berdasarkan hasil penelitian dan simpulan sebagaimana dikemukakan sebelumnya, maka untuk itu dapat dirumuskan beberapa saran:

1. Untuk SMP Swasta khususnya di Jakarta Selatan perlu mengembangkan kegiatan yang dapat mendorong pada peningkatan kemandirian, sehingga para siswa diharapkan dapat memiliki kompetensi yang dapat digunakan dalam pembelajaran, berkaitan dengan tugas profesinya.

2. Untuk peneliti lebih lanjut perlu peningkatan lebih jauh dan mendalam tentang faktor - faktor yang berkaitan kemandirian dengan pendekatan yang berbeda salah satunya peneliti harus menggunakan pendekatan kualitatif, sehingga dapat menggali lebih cermat dan mendalam tentang faktor - faktor lain yang mempengaruhi kemandirian.

\section{REFERENCES/DAFTAR PUSTAKA}

Cahyaningrum, D. (2017). Pengaruh Motivasi Belajar dan Persepsi Siswa Tentang Metode Mengajar Guru Terhadap Prestasi Belajar Memproses Dokumen Dana Kas Kecil Peserta didik Kelas XI Akuntansi SMK Negeri 4 Klaten Tahun Ajaran 2016/2017. In Skripsi.

Fauziah. (2017). Hubungan Antara Motivasi Belajar dengan Minat Belajar Siswa Kelas IV SDN Poris Gaga 05 Kota Tangerang. Jurnal JPSD, $4,49$.

Hamalik, O. (2016). Proses Belajar Mengajar.

Kompas. (2021). Pengertian-kemandirian-tahap-perkembangannya-dan-faktornya. Https://Www.Kompas.Com.

Majid, L. O. A. (2021). Pengaruh Kemandirian, Lingkungan, Dan Motivasi Belajar Terhadap Prestasi Belajar IPS. Jurnal Penelitian Dan Pendidikan IPS, 15(1), 25-32.

Meilani. (2021). Impak Minat Dan Motivasi Belajar Terhadap Hasil Belajar Siswa. Jurnal Pendidikan, 1, $80-93$.

Nurhasanah. (2016). Minat Sebagai Determinan Hasil Belajar Siswa. Jurnal Pendidikan, 1, 135-142.

Prasetyono, H., \& Ramdayana, I. P. (2020). Pengaruh servant leadership, komitmen organisasi dan lingkungan fisik terhadap kinerja guru. Jurnal Akuntabilitas Manajemen Pendidikan, 8, 108-123.

Prasetyono, H., Ramdayana, I. P., \& Estiningsih, W. (2020). Peningkatan Kinerja Guru SMK melalui Lingkungan Kerja dengan Mengoptimalkan Efektivitas Kepemimpinan dan Komitmen Tugas. Jurnal Manajemen Dan Supervisi Pendidikan, 4, 255-266.

Ratnasari. (2017). Hubungan minat belajar terhadap prestasi belajar matematika. Jurnal Psikoborneo, $5,400-405$.

Rusmiati. (2017). Pengaruh Minat Belajar Terhadap Prestasi Belajar Bidang Studi Ekonomi Siswa MA AL Fattah Sumbermulyo. Jurnal IImiah Pendidikan Dan Ekonomi, 1, 21-36.

Silvia Yanti, E. S. (2017). Kemandirian Belajar Dalam Memaksimalkan Kualitas Pembelajaran.

Widyaningrum. (2016). Analisis Kesulitan Siswa dalam Mengerjakan Soal Cerita Matematika Materi Aritmatika Sosial Ditinjau dari Gaya Belajar Siswa Kelas VII SMP NEGERI 5 Metro. Jurnal Iqra, 1, 166-190. 